\title{
The Influence Factors of Impulse Buying Online Behavior
}

\author{
Vidyarini Dwita ${ }^{1}$, Retsi ${ }^{*}$ \\ ${ }^{1}$ Universitas Negeri Padang, Padang, Indonesia, $\square$ vidyarinidwita1301@gmail.com \\ ${ }^{2}$ Universitas Negeri Padang, Padang, Indonesia, $₫$ retsiyusril15@gmail.com \\ *Corresponding Author
}

\begin{abstract}
The purpose of this study is to examine the relationship between between hedonic shopping motivation, online store beliefs, sales promotion and impulse buying online of fashion products. A total of 151 questionnaires were collected to test with multiple regression analysis. The study sample includes students of Economic Faculty at Universitas Negeri Padang who have experienced impulse buying online via social media. The results imply that hedonic shopping motivation, online store beliefs, and sales promotion significant influence on impulse buying online.
\end{abstract}

Keywords: impulse buying behavior, impulse buying online, hedonic motivation, online store, sales promotion

\section{Introduction}

Technology has dramatically changed the shopping experienced for consumers especially online shopping with using digital platforms. Internet has changed the way of consumer's to buying products through online shopping. This paper focuses on a factors that influence the impulse buying online. Consumer behaviour in conventional shopping contexts has acquired a number of study to developed the models of buying process. On the other hand, the developing models to get better insight of online shopping process be modified to identifies key factors influencing online consumer behaviour.

Impulse buying is defined as shopping behaviour that occurs unplanned with the state of quick decision maker without thinking of causation (Muruganatham \& Bhakat, 2013). Moreover, impulse buying tendency is defined as the "degree to which an individual is likely to make unintended, immediate, and unreflective purchases" ( Jones et al., 2003, p.506) Furthermore, Amiri et al ( 2012) explain that impulse buying is a sudden and strong tendency to make direct purchases, the sudden motive for buying is complicated and sometimes causes emotional conflict and impulse buying may also occur without considering the results .

Several studies have considered that consumers personality traits can represent impulsive behaviour to determine the stage of a person's impulse buying tendency. Beatty and Ferrell, 1998; Rook and Fisher, 1995). Youn and Faber (2000) discovered that impulse buying behaviour was related to a personality trait where impulse buyers has lack of control with their cognitive attitude of their impulse purchasing. Online impulse buying is an unplanned purchase decision, influenced by several factors such as hedonic motivation, utilitarian motivation, social shopping, adventure shopping, perceived usefulness, perceived enjoyment, visual appeal information fit-to-task, and impulse to buy impulsively (Yi-Shih Loa et al., 2016; Akram et al., 2017).

\section{Theoretical Backgrounds \\ The Impulsive Buying Behaviour \\ Internals Factor}

Consumers are stimulated by internal and external factors, but usually the impulse buying behaviour was driven by internal factors. The characteristic of individual play a part in encouraging their impulse buying behaviour. Internal cues such as emotional stages, the consumer's normative evaluation of impulse buying engagement, and demographic are considered the factors that impact before buying the products. (Kacen and Lee, 2002). Moreover, a person's emotional phase, mood and 
self-feelings can be identified as the condition of a person's affective (Youn, 2000). Internal stimuli are processed by the consumer affective or cognitively resulting in impulsive or non-impulsive behaviour. The consequence of feeling like "irresistible urge to buy" drive the impulse purchase ( Coley and Burgess, 2003).

Hedonic shopping motifs are based on emotions, feelings of comfort, and joy. According to Paden (2010: 886) defines the hedonic shopping motivation, namely consumers shop because they feel happy when shopping either with friends or with family. Hedonic motives lead a person to buy for pleasure and enjoyment (Gultejin and Ozer, 2012). Hedonic motivation is believed to be more personal and subjective when compared to utilitarian motives for an individual, producing emotions of pleasure and pleasure associated with impulsive buying (Dey \& Sristava 2017). In buying behaviour with hedonic motivation, consumers consider shopping as an excitement, satisfaction and pleasure for the five senses.

\section{External Factors}

External factors of impulse buying to direct the attention to marketing cues or something that incites to action that function and manged by the marketer to make effort to attract consumers into buying behaviour ( Youn and Faber, 2000). Consumers particular instance for impulsively process when buy items that visually come with anything that stimulate such as promotional incentives (Dholakia, 2000; Rook, 1987). Engaged new customers within create attractive retail web site need to encouraged with promotion and cross-selling to current customers and to get attention from new customers by stimulate the impulse purchase of complimentary items or improved better items.

In 2005 , a study conducted by Shop.org/Biz showed there was a 30 percent increase in online sales after completing accelerate marketing programs such as direct e-mail promotions, free shipping, gift idea centres, suggested items, and featured sales item pages. The study also found that aggressive marketing stimuli such as advertisements, visual elements, or promotional gifts and thus engage in in-store browsing impact to higher impulse buying tendency which showed high frequently to respond urges to buy impulsively.

Sales promotion is the main element in marketing, consisting of a collection of short-term incentive tools designed to stimulate consumers in purchasing products or services (Kotler at.el., 2016). "Social promotions are defined here as" special products or services that are specifically a product or service, typically used in conjunction with other advertising or personal selling programs "according to Grewal and Levy (2014: 572). Promotion of sales is a special incentive or program that encourages consumers to buy certain products or services usually used in conjunction with advertising or direct sales programs.

According to Peter and Olson (2005), cognitive refers more to thinking processes, namely knowledge, meaning or meaning, and beliefs. A person's cognitive aspect refers to how consumers understand products, think and interpret products, and can lead to impulse buying, minimize the possibility to consider, and think about trust in online stores so that they make impulsive purchases. Verhagen et al. (2011) shows that online store beliefs have a significant effect on impulse buying. The cognitive aspects related to someone understand, thinks and interprets information according to their unplanned bsuying tendencies which make consumers give more responsive to their affective state and less responsive to cognitive state to engaged their impulse buying behaviour ( Dholakia, 2000 ; Rook, 1987 ; Youn and Faber, 2000).

\section{Hedonic Shopping Motivation and Online Impulse Buying}

The need for hedonic consumption as a need to fulfill something that is pleasing to the individual and pleasure when shopping (Siew and Chin, 2015). Hedonic shopping motifs are based on emotions, feelings of comfort, and joy. According to Paden (2010: 886) defines the hedonic shopping motivation, namely consumers shop because they feel happy when shopping either with friends or with family. Hedonic motives lead a person to buy for pleasure and enjoyment (Gultejin and Ozer, 2012).

\section{Online Store Beliefs and Online Impulse Buying}

Internal factors that encourage consumers to make impulsive purchases include cognitive and affective conditions. According to Peter and Olson (2008), cognitive refers more to thinking 
processes, namely knowledge, meaning or meaning, and beliefs. A person's cognitive aspect refers to how consumers understand products, think and interpret products, and can lead to impulse buying, minimize the possibility to consider, and think about trust in online stores so that they make impulsive purchases. According to the research of Verhagen et al. (2011) "The Influence of online store beliefs on consumer online impulse buying: a capital and empirical application" shows that online store beliefs have a significant effect on impulse buying.

\section{Sales Promotion on Online Impulse Buying}

The sales promotion aims to stimulate customer needs and urge customers to immediately buy products from certain brands. The benefits of consumers from sales promotions can be divided into hedonic benefits (entertainment, value, and exploration) and utilitarian benefits (convenience and saving money). Thus, the situation of impulsive buying must involve a sales promotion stimulus. Impulse buying creates an excitement to buy or is a behaviour stimulus to satisfy life's needs. Study by Negadeepa et al, (2015) showed that sales promotion in the form of rabate \& discount offer and loyalty program had a significant effect on impulse buying.

\section{Methods}

The type of research that will be conducted is causative research. Thus research explains and illustrates the influences between the independent variable of hedonic shopping motivation, online store beliefs and sales promotion with dependent variable is impulse buying online. The population in this study are all students of Economic Faculty at Universitas Negeri Padang who have experienced with impulse buying online by taking sample of 151 respondents. The measurement used to measure the respondent's response is to use a Likert scale with a scale range of $5=$ "Strongly Agree" to $1=$ "Strongly Disagree ".

Table 1 Research Variables

\begin{tabular}{|c|c|c|}
\hline $\begin{array}{l}\text { Variable } \\
\text { Impulse Buying } \\
\text { Online }\end{array}$ & $\begin{array}{l}\text { Indicators } \\
\text { 1. Purchase was spontaneous } \\
\text { 2. Purchase was unplanned } \\
\text { 3. Did not intend to purchase before shopping } \\
\text { trip } \\
\text { 4. Before visiting the site, did not have the } \\
\text { intention to do the purchase } \\
\text { 5. Could not resist to do the purchase at the } \\
\text { site }\end{array}$ & $\begin{array}{l}\text { Source of } \\
\text { Verhagen (2011) }\end{array}$ \\
\hline $\begin{array}{l}\text { Hedonic Shopping } \\
\text { Motivation }\end{array}$ & $\begin{array}{ll}\text { 1. } & \text { Novelty } \\
\text { 2. } & \text { Fun } \\
\text { 3. } & \text { Praise from others } \\
\text { 4. } & \text { Escapism }\end{array}$ & $\begin{array}{l}\text { Dipnajan Kumar et.al } \\
\text { (2017) }\end{array}$ \\
\hline Online Store Beliefs & $\begin{array}{l}\text { 1. Merchandise Attractiveness } \\
\text { 2. Ease of use } \\
\text { 3. Enjoyment } \\
\text { 4. } \text { Website Communication Style }\end{array}$ & $\begin{array}{l}\text { Verhegen, Tibert et.al } \\
\text { (2011) }\end{array}$ \\
\hline Sales Promotion & $\begin{array}{l}\text { 1. Rabate\& Discount Offer } \\
\text { 2. Coupon } \\
\text { 3. Loyalty Program } \\
\text { 4. Price Packs } \\
\text { 5. } \text { Contest } \\
\end{array}$ & Nagadeepa et.al (2015)1. \\
\hline
\end{tabular}

\section{Result and Discussion}

The demography of respondents for this study were grouped by gender, age, and education, The results based on this study majority of respondents are women, with percentage $68,9 \%$ of total 
respondents with aged between 20 and 29 years old and educational level were students at university.

The multiple regression was used to analyze the relation between hedonic shopping motivation $(\mathrm{X} 1)$, online store beliefs $(\mathrm{X} 2)$, and sales promotion $(\mathrm{X} 3)$ toward Impulse Buying Online $(\mathrm{Y})$.

Table 2 Results of Multiple Linear Regression Analysis

\begin{tabular}{lccc}
\hline \multicolumn{1}{c}{ Variable } & $\begin{array}{l}\text { Coefficient } \\
\text { regression }\end{array}$ & $\mathbf{t}_{\text {cal }}$ & sig. \\
\hline Constant &,- 822 &,- 381 &, 704 \\
\hline Hedonic Shopping Motivation $\left(\mathrm{X}_{1}\right)$ &, 172 & 3,653 &, 000 \\
\hline Online Store Beliefs $\left(\mathrm{X}_{2}\right)$ &, 121 & 2,216 &, 028 \\
\hline Sales Promotion $(\mathrm{X} 3)$ &, 185 & 2,039 &, 043 \\
\hline $\mathrm{F}$ & 16,140 & &, $000^{\mathrm{b}}$ \\
\hline R Square & & &, 248 \\
\hline
\end{tabular}

The multiple regression equations can be made as follows:

$$
\mathrm{Y}=-0.822+0.172 \mathrm{X} 1+0.121 \mathrm{X} 2+0.185 \mathrm{X} 3
$$

From the multiple linear regression equation above, it can be seen that the constant value is -0.822 , which means that with the influence of the variables hedonic shopping motivation, online store beliefs, and sales promotion, impulse buying online has reached - 0.822. From the quation above, it was found that hedonic shopping motivation (X1) variable regression coefficient is 0.172 . With the assumption that the greater influence of hedonic shopping motivation, the customers to do impulse buying online will be increasing. Furthermore, it was found that online store beliefs (X2) variable regression coefficient is 0.121 , it means that the greater influence of online store beliefs, the customers to do online impulse buying will be increasing. Finally, it can be seen that sales promotion (X3) variable regression coefficient is 0.851 , it means that the greater influence of sales promotion, the customers to do impulse buying online will be increasing.

Hypothesis 1 : There is significant influence between hedonic shopping motivation and impulse buying online. Based on the results of analysis test known significant value of 0,000 which is less than 0,05. The result of this study are consistent with the research conducted by Dipinjan Kumar (2017) which says that hedonic shopping motivation have a significant influence on online impulse buying. Research Chang, H.-J., Eckman, M., \& Yan, R.-N. (2011) also supports this hypothesis which states that consumers with motivation based on hedonic needs can be involved in activities related to shopping spontaneously involving multi-censor, fantasy, and emotional experiences. According to Rezaei, S., et al, (2016) hedonic motivation is when someone is more likely to spend time doing something, making new discoveries and doing what makes them happy. It will encourage someone to do impulsive buying online

Hypothesis 2: There is significant influence between online store beliefs and impulsive buying online. Based on the results of analysis test known significant value of 0,028 which is less than 0,05 . The result of this study are consistent with the research conducted by Verhagen (2011) which says that online store beliefs have a significant influence on online impulse buying. This study supported by Becerra, E. P., \& Korgaonkar, P. K. (2011) states that online beliefs can be interpreted as a situation where consumers feel uncertain and risky in transacting online. Confidence can be linked to the benefits of online search or online search fees or both.

Hypothesis 3: There is significant influence between sales promotion and impulse buying online. Based on the results of analysis test known significant value of 0,043 which is less than 0,05 . The result of this study are consistent with the research conducted by Nagadeepa (2015) which says that sales promotion have a significant influence on online impulse buying. This study supported by Cummins (2008) states that sales promotions consist of value promotions such as free sweepstakes, major premiums, container promotions and competitions and price promotions such as money from 
coupons, pence off flashes, extra and attractive packages. Also supported by Awunyo et al., (2013) sales promotion is achieved by persuading and providing customer or consumer information on new or existing products. Sales promotions often include the value of promotions or price promotions. So, sales promotion will influence customers to do impulse buying online behavior.

\section{Conclusion}

Based on the results of research conclude that hedonic shopping motivation, online store beliefs, and sales promotion has significant influences on impulse buying online for students at Universitas Negeri Padang. In conclusion, emotional stage such as hedonic motivation has consider to most stimulate consumers in impulse buying while marketing cues such as promotional and attractive retail web site are encouraged potential customers being impulse buying with visually encounter. Further development of hedonic motivation, belief web store and sales promotion that impact to impulse buying online behaviour may allow a more factors that trigger the behaviour. For the future research is better to explore more variables that can influenced impulse buying online.

\section{References}

Akram, U., Hui, P., Kaleem Khan, M., Tanveer, Y., Mehmood, K., \& Ahmad, W. (2018).

How website quality affects online impulse buying. Asia Pacific Journal of Marketing and Logistics, 30(1), 235-256. doi:10.1108/apjml-04-2017-0073

Amiri et al. (2012). Evaluation of Effective Fashionism Involvement Factor Effect On Impulse Buying Of Customer Condition of Interrelation Between These Factors. Journal of Basic and Applied Scientific Research. Vol 9, pp. 413-9419.

Awunyo-Vitor, D., Ayimey, E.K. and Gayibor, R.A. (2013). “Does Sales Promotion Influence Buyer Behaviour? A Study of PZ Cussons Limited" British Journal of Economics, Management and Trade, 3 (2), 141- 152.

Beatty, S.E. and Ferrell, M.E. (1998), “Impulse buying: modeling its precursors", Journal of Retailing, Vol. 74 No. 2, pp. 169-91.

Becerra, E. P., \& Korgaonkar, P. K. (2011). Effects of trust beliefs on consumers' online intentions. European Journal of Marketing, 45(6), 936-962.

Chang, HJ., Eckman, M., \& Yan, RN. (2011). Application of the Stimulus Organism Response model to the retail environment: the role of hedonic motivation in impulse buying behavior. The International Review of Retail, Distribution and Consumer Research, 21(3).p.233-249

Coley, A. and Burgess, B. (2003), "Gender differences in cognitive and affective impulse buying", Journal of Fashion Marketing \& Management, Vol. 7 No. 3, pp. 282-95.

Cummins, J. (2008). Sales Promotion: How to create, implement and integrate campaigns that really work (8th ed.). London, UK: Kogan Page.

Dholakia, U.M. (2000), “Temptation and resistance: an integrated model of consumption impulse formation and enactment", Psychology \& Marketing, Vol. 17 No. 11, pp. 955-82.

Dipanjan Kumar Dey, \& Ankur Srivastava, (2017) "Impulse buying intentions of young consumers from a hedonic shopping perspective", Journal of Indian Business Research, Vol. 9 Issue: 4, pp.266282, https://doi.org/10.1108/JIBR-02-2017-0018

Grewal.D dan Levy, M. 2014. Marketing, Fourth Edition, The McGraw-Hill, New York

Gültekin, Beyza \& Leyla Ozer. (2012). The Influence of Hedonic Motives and Browsing On Impulse Buying. Journal of Economics and Behavioral Studies Vol. 4, No. 3, pp. 180-189.

Jones, M.A., Reynolds, K.E., Weun, S. and Beatty, S.E. (2003), “The product-specific nature of impulse buying tendency", Journal of Business Research, Vol. 56 No. 7, pp. 505-12.

Kacen, J.J. and Lee, J.A. (2002), "The influence of culture on consumer impulse buying behavior", Journal of Consumer Psychology, Vol. 12 No. 2, pp. 163-76.

Kotler, P. \& Keller, Kevin L. 2016. Marketing Management, 15th Edition, Pearson International Edition. New Jersey: Prentice Hall. 
Muruganantham, C., and S. R. Bhakat. (2013). A Review of Impulse Buying Behavior. India:International Journal of marketing Studies

Nagadeepa, C, J.Tamil. S dan Pushpa A. 2015.Impact of sales promotion technique on consumers Impulse buying behavior toward apparel at Bangalore. Asia journal of management science and education. Vol 4 (1)

Paden, N.2010. Virtual Cart Abandonment: Addressing Hedonic and Utilitarian Shopping Motives.ASBBS Annual Conference.Volume 17 Nomber 1. Las Vegas.

Peter, J. P. \& Olson, J. C. (2008). Consumer behaviour and marketing strategy (8th ed.). New York: McGraw-Hill.

Rook, D.W. and Fisher, R.J. (1995), "Normative influences on impulsive buying behavior", Journal of Consumer Research, Vol. 22, pp. 305-13.

Sajad Rezaei, Faizan Ali, Muslim Amin, Sreenivasan Jayashree, (2016) "Online impulse buying of tourism products: The role of web site personality, utilitarian and hedonic web browsing", Journal of Hospitality and Tourism Technology, Vol. 7 Issue: 1, pp.60-83, https://doi.org/10.1108/JHTT-03-2015-0018

Shop.org (2005), "Online retail sales, profitability continue to climb, according to shop.org/forrester research", May 24, available at: www.shop.org/press/05/052405.asp

Siew Lin Chuah \& Chin Chuan Gan. 2015. The influence of individual internal factors on impulse buying Behavior through online shopping. Global journal of business and social science review.GJBSSR, Vol. 1 (1): 60-70. ISSN 22- 8506.

Verhagen, Tibet \& Willemijn van Dolen. 2011. The influence of online store beliefs onconsumer online impulse buying: A model and empirical application.https://doi.org/10.1016/j.im.2011.08.001

Yi-Shih Loa, Louis., Sheng-Wei Lin, Li-Yi Hsu. 2016. Motivation for online impulse buying: A twofactor theory perspective, International Journal of Information Management 36 (2016)759-772, https://doi.org/10.1016/j.ijinfomgt.2016.04.012

Youn, S.H. (2000), "The dimensional structure of consumer buying impulsivity: measurement and validation", unpublished doctoral dissertation, University of Minnesota, Minneapolis, MN.

Youn, S.H. and Faber, R.J. (2000), "Impulse buying: its relation to personality traits and cues", Advances in Consumer Research, Vol. 27, pp. 179-85. 